\title{
Perceived Possibility of Disclosure and Ethical Decision Making in an Information Technology Context
}

\author{
Alireza Bolhari \\ Dpt of Information \\ Technology \\ Management, Science \\ and Research Branch, \\ Islamic Azad University, \\ Tehran, Iran \\ alireza@bolhari.com
}

\author{
Reza Radfar \\ Dpt of Industrial \\ Management, \\ Science and Research \\ Branch, Islamic Azad \\ University, Tehran, \\ Iran \\ radfar@gmail.com
}

\author{
Mahmood Alborzi \\ Dpt of Information \\ Technology Management, \\ Science and Research \\ Branch, Islamic Azad \\ University, Tehran, Iran \\ mahmood_alborzi@ \\ yahoo.com
}

\author{
Alireza Poorebrahimi \\ Dpt of Management \\ and Accounting, \\ Islamic Azad \\ University Karaj, \\ Iran \\ poorebrahimi@ \\ gmail.com
}

\author{
Mahmood Dehghani \\ School of Behavioral \\ Sciences and Mental \\ Health, Iran University \\ of Medical Sciences, \\ Tehran, Iran \\ mdehghani2004@ \\ gmail.com
}

\begin{abstract}
To date, substantial research studies have been conducted in the field of ethical decision making in many disciplines. However, ethical efforts in the context of information technology have been limited. In this research, a focus has been put on modeling ethical decision making in cyberspace with emphasis on business intelligence scenarios. The model is comprised of six exogenous and two endogenous constructs, among them seven were delicately selected from valid and empirically tested ethical models and the eighth one is developed by the authors. After pre-testing the model by experts, reliability, convergent and discriminant validities were approved. Data were collected from 188 IT personnel in the banking industry of Iran. Results revealed that the perceived importance of an IT ethical issue, ethical judgment, ethical obligation, perceived possibility of disclosure, ego strength, and locus of control directly impact ethical intention. However, no impact from law on ethical obligation and codes of ethics on ethical intention was observed. As shown, a higher possibility on acting unethically occurs when the person feels confident that his/her actions will go unnoticed.
\end{abstract}

Keywords-information technology; business intelligence; ethical decision making; perceived possibility of disclosure; IT ethics

\section{INTRODUCTION}

Ethics, as in its simple definition delivered in [1], is the values and principles leading to a right or wrong behavior. The perception of ethics in the digital world slightly varies from brick and mortar organizations and in most cases, recognition of a right or wrong behavior gets complicated. Organizations, which typically live in uncertain and vague atmosphere [2], have faced noteworthy ethical issues. In order to decrease these unethical actions, managers should lead employees toward a more organizational ethical environment [3]. This concern about ethical decision making in information technology (IT) has always been an interest point for researchers [4]. In [5], it was noted that ethical issues in business management have long-term and wide-spread adverse effects. Furthermore, results were identified that may lead to challenges for managers. In [6], authors have identified ethical decision making as a fundamental factor that influences information systems' success including business intelligence systems. Others have noted that ethical issues in the context of businesses bring decreased productivity, increased uncertainty [4], elimination of work opportunities, environmental pollution [5], higher work absence and customer dissatisfaction [1]. In [7], the author urged business managers on the subject of ethical decision making and its potential adverse influences. In [8], authors stated that studying the way an individual makes ethical decisions improves ethical decision making in organizations.

In [9], it was proposed that when dealing with computers, the theory of reasoned action fails and does not satisfactorily model ethical decisions. In [10], an investigation about ethical decision making methods in knowledge management systems was conducted and a number of policies was suggested to maintain an ethical-based climate organization-wide. In [11], authors called the importance of ethical issues in computer and internet usage as a concept that is "lost in cyberspace". They conducted their study around ethical judgment and ethical intention and mainly considered gender differences. In [12], the chance of being caught as influencing ethical behavior was discussed but it was also implied that individuals with greater technical knowledge may be more aware of the ways they may get caught, and may be more cautious than others.

A very early approach on IT ethical decision making was presented in [13] where an IT model with two new factors: ego strength and locus of control was proposed [13]. This model 
was retested in [14] with about 1990 observations. Although some contradictions were found, the overall model was reapproved. In [15], authors modeled IT ethical decision making based on reasoned actions, perceived importance, planned behaviors, and individual characteristics. They also included age and sex in their models. In [16], authors proposed a process for IT ethical decision making by investigating information system students. They mainly focused on age, sex and religion as the influencing factors.

\section{IT ETHICAL DECISION MAKING MODEL}

\section{A. Perceived Importance of an Ethical Issue}

In the ethical decision making literature, scholars have referred to the perceived importance of an ethical issue in different names such as ethical perception [17], perceived ethical problem [18] and ethical issue [19]. In [20], it was stated that perceived importance of an ethical issue corresponds to the importance, significance, and fundamentality of an issue. An instrument was proposed to measure the perceived importance that later became a dominant instrument in this area. In [21], authors tested the impact of perceived importance of an ethical issue on ethical intention among 235 business managers who were randomly selected and found a positive impact. In a study among higher education students and with deployment of three ethical scenarios, it was reported that perceived importance is an indicator of ethical judgment [22]. In information technology, equivalent findings show that perceived importance affects ethical intention and judgment $[15,23]$. Accordingly, hypothesis $1 \mathrm{a}$ and $1 \mathrm{~b}$ are as follows:

- H1a: Perceived importance of an ethical issue positively influences ethical intention.

- H1b: Perceived importance of an ethical issue positively influences ethical judgment.

\section{B. Ethical Judgment and Ethical Obligation}

According to [24], ethical judgment refers to a judgment made ethically according to the correctness, acceptability and appropriateness of an issue. This is in accordance with the definition of ethical judgment in [25]: decision makers' assessment of correct behavior in an ethical decision making situation. In a simplified definition, ethical judgment is one's evaluation of his/her action to be good or bad [26]. Previous research studies have shown a meaningful relationship between ethical judgment and ethical intention. In an early research about software piracy, In [27], authors revealed that ethical judgment positively predicts ethical intention in copying and distributing software packages illegally. The same finding is approved in [28] between peer groups. This was achieved by conducting a research to investigate the relationship between ethical judgment and ethical intention in scenarios about unethical cases. Another research has shown a positive and influential impact on ethical intention between automobile salespeople [17]. The same findings are presented by others [29-33]. As a result, the second hypothesis is as follows:

- H2: Ethical judgment positively influences ethical intention.
Ethical obligation or normative belief [14] is the alignment of the decision maker's behavior by personal and social pressures [34]. For the first time, in [35] a scale was developed with one question about organ donation to measure ethical obligation. This question further became popular among other research studies. For instance, in [15] and [36] authors investigated the impact of demographic characteristics on ethical decision making among computer college students and used the construct from [35] to measure ethical obligation. They showed that ethical obligation is an indicator of ethical intention. Besides, ethical judgment is found to predict ethical obligation [27]. This relationship is further investigated by other scholars and the same finding is found [29, 31]. Therefore, we theorized hypotheses three and four as follows:

- H3: Ethical judgment positively influences ethical obligation.

- H4: Ethical obligation positively influences ethical intention.

\section{Law and Codes of Ethics}

Law is the "rule and measure of actions directing them to proper ends" [37] and forces individuals to conform their actions to norms. Additionally, law reveals preferences of a community or society [38, 39, 17]. According to these definitions, it seems apparent that law and codes of ethics must -to some degree- confine decision makers' behaviors toward proper ends. In this regard, Dunfee [39] believed that ethics is deeply tangled with law and they cannot be realized without another one.

In an early research in this domain, the role of codes of ethics on computer misuse is investigated and results showed that company's codes of ethics slightly limits behavior of information system personnel [40]. Besides, Hunt and Vitell [41] mentioned legal environment as an influential factor in ethics. They argued that law and codes of ethics potentially limit decision makers' intention to commit more ethical actions. This happens when law influences ethical obligation and codes of ethics influences ethical intention. Accordingly, hypotheses 5 and 6 are as follows:

- H5: Law has a significant impact on ethical obligation.

- H6: Codes of ethics has a significant impact on ethical intention.

\section{Ego Strength and Locus of Control}

One of the most important factors that influence human behavior is ego strength [42]. This relates to the ability to bear stress and tension in various occasions [43]. Accordingly, in [44] ego strength was defined as one's proficiency to control his/her instinct and social needs. In other ethical research studies, ego strength has also been called "self-identity" [45, $46,47]$. Ego strength has been introduced to the field of ethical decision making since 1986 [48] and research studies have approved that it impacts ethical intention [23, 15].

Locus of control, on the other hand, refers to one's tendency to relate his/her success or failure to internal or external factors. In another word, one's belief about their 
behavior and its outcomes is called locus of control [49]. In [50], authors reported no significant relation between locus of control and ethical intention. They concluded that locus of control does not relate to ethical intention in sales managers. The same finding was observed in [51] in workplace environments. This however, is against the findings of an early study that reported a positive relationship between locus of control and ethical intention [52]. Even though, one year later, authors [53] reported a contradicting finding stating that no relation was observed among management students. In [54], it was stated that locus of control is an indicator of ethical behavior among the United States managers and executives. The higher locus of control determined more ethical decisions.

For the first time in the field of information technology, ego strength and locus of control was applied to assess ethical behavior in [13]. It was found that ego strength and locus of control influence ethical intention. Moreover, in [14] authors testified ego strength as an indicator of ethical intention among IT students. Thus, the corresponding hypotheses are:

- H7: Ego strength has a significant impact on ethical intention.

- H8: Locus of control has a significant impact on ethical intention.

\section{E. Perceived Possibility of Disclosure}

Through the extensive review of the decision making literature, we found that the perceived possibility of disclosure of decision results (we named it perceived possibility of disclosure or its short form perceived disclosure) has not been investigated before and may have direct or indirect effect on ethical decision making. The following scenarios clarify the core meaning of our construct:

- In a company, payrolls are sent to personnel's email addresses. Sarah, by chance, has found her colleague's (Sam) email password. In one instance, consider the situation that Sarah is upmost confident that if she checks Sam's payroll, he will not notice it. In another instance, she is almost assured that Sam would notice that she has checked his payroll. In the two mentioned instances, what are the possibilities of checking the payroll? Are they the same?

- Adam works for a company that develops software packages. For personal reasons, he needs a system restore application to repair his own laptop. In his company's products' list, there is a $120 \$$ system restore application. Consider two cases. In one case, he certainly knows that no one would notice if he takes home a copy of the software. In another case, he that feels the possibility of disclosure is high. This means that his boss, for example, will notice his action and this would have adverse consequences for him. Will Adam perform the same actions in either case? Does his intention vary?

Accordingly, hypothesis 9 is as follows:

- $\quad$ H9: Perceived possibility of disclosure has significant impact on ethical intention.
To encapsulate, our model of ethical decision making in the context of information technology and above mentioned hypotheses are shown in Figure 1.

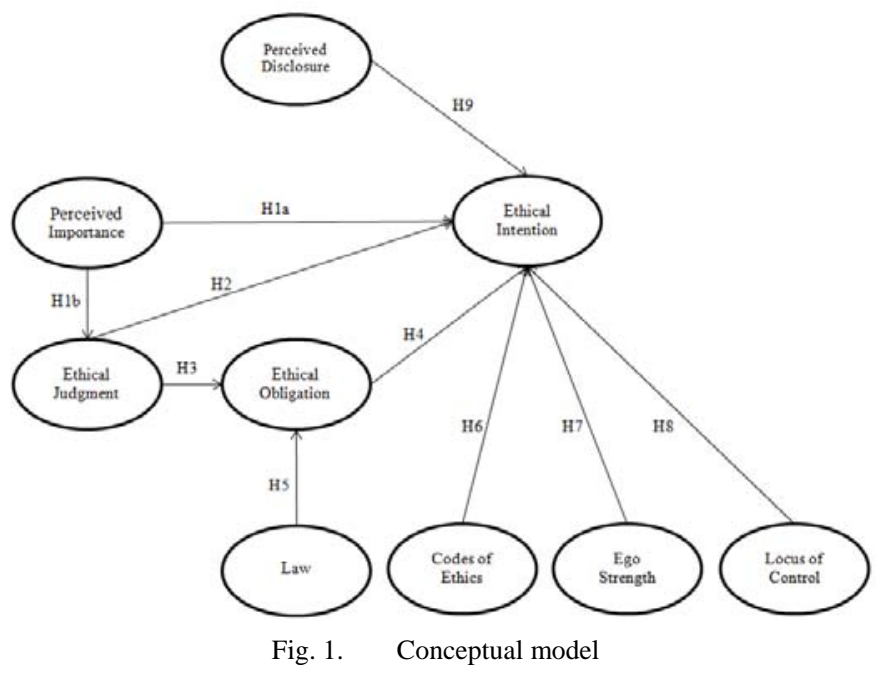

III. METHODS

\section{A. Samples}

The test population was comprised of business intelligence experts, managers, supervisors and end-users that had professional experience in banking industry. They were all experts or familiar with business intelligence concepts and techniques such as data mining, recommender systems, data warehouse, performance dashboards and scorecards, reality mining, etc. PLS states that the minimum sample size must be at least 10 times of the number of structural paths to a specific construct [31]. In our model, there are seven paths to ethical intention; as a result, 70 samples provides a sufficient sample. Of the 364 IT personnel of a bank in Iran, 188 (male=107 and female $=81$ ) participated in this research. The average age was 39 and it varied from 18 to 69 . Of the respondents, 87 (46.3\%) had less than 5 years of related experiences and 65 (34.6\%) had 5 to 10 years.

\section{B. Constructs}

The basis of data collection was a questionnaire employed in preceding research studies. Constructs were selected from the valid ones in the literature (Table I). Of the constructs, we developed the perceived possibility of disclosure. Our questionnaire started with three sample ethical decision making scenarios to align respondents with the context of IT ethical decision making. Following the scenarios, we presented 33 questions for eight constructs and face-validated our questionnaire by pre-testing among several experts and university professors [57].

\section{Confirmatory Factor Analysis}

SmartPLS 2.0.M3 was used for confirmatory factor analysis (CFA), which is a path modeling software based on partial least-squares. In [58], it was stated that SmartPLS requires less 
demands and samples in comparison with other approaches like structural equation modeling. This leading point makes partial least-square method a valid and commonly referenced in data analysis and surveys [59, 58, 60]. Prior to data analysis, reliability and validity of the constructs must be measured [61]. Convergent and divergent (discriminant) validity are parts of construct validity which indicate the measurements within our constructs. As a result, we explored these three parameters for our constructs as follows. Reliability measures the overall consistency of a measure. Confirmatory factor analysis in partial least squares presents composite reliability for every construct and the overall Cronbach's alpha. The internal consistency is considered acceptable if Cronbach's alpha is exceeded from 0.70 [62, 61]. Table II demonstrates the reliability of our constructs.

TABLE I. CONSTRUCTS OF THE QUESTIONNAIRE

\begin{tabular}{|c|c|c|}
\hline Construct & Questions & Reference \\
\hline Perceived Importance of Ethical Issue (PI) & $1-4$ & {$[20]$} \\
\hline Ethical Judgment (EJ) & $5-7$ & {$[24]$} \\
\hline Ethical Obligation (EO) & $8-10$ & {$[36]$} \\
\hline Perceived Possibility of Disclosure (PD) & $11-12$ & {$[55]$} \\
\hline Locus of Control (LOC) & $13-24$ & current study \\
\hline Ego Strength (ES) & $25-31$ & {$[13]$} \\
\hline Law & 32 & {$[13]$} \\
\hline Codes of Ethics & 33 & {$[2]$} \\
\hline
\end{tabular}

TABLE II. RELIABILITIES OF THE CONSTRUCTS

\begin{tabular}{|c|c|c|c|c|c|}
\hline & $\begin{array}{c}\text { No. } \\
\text { of } \\
\text { items }\end{array}$ & t-values & $\begin{array}{c}\text { Factor } \\
\text { Loadings } \\
\text { (FL) }\end{array}$ & $\begin{array}{c}\text { Cronbach's } \\
\text { Alpha (CA) }\end{array}$ & $\begin{array}{c}\text { Composite } \\
\text { Reliability } \\
\text { (CR) }\end{array}$ \\
\hline Criteria & - & t-value $>\mathbf{1 . 9 6}$ & $\mathbf{F L}>\mathbf{0 . 7 0 7}$ & $\mathbf{C A}>\mathbf{0 . 7 0}$ & $\boldsymbol{C R}>\mathbf{0 . 7 0}$ \\
\hline PI & 4 & 50.3 & 0.89 & 0.79 & 0.90 \\
\hline EJ & 3 & 9.4 & 0.79 & 0.83 & 0.88 \\
\hline EO & 3 & 16.7 & 0.81 & 0.72 & 0.79 \\
\hline PD & 2 & 83.6 & 0.95 & 0.81 & 0.87 \\
\hline LOC & 12 & 14.3 & 0.82 & 0.89 & 0.95 \\
\hline ES & 7 & 50.9 & 0.92 & 0.88 & 0.91 \\
\hline LC & 2 & 61.2 & 0.91 & 0.78 & 0.88 \\
\hline
\end{tabular}

We examined convergent validity by the criteria proposed in [63]. Firstly, each factor loadings must exceed 0.70 (to be precise: 0.707 ) and be significant. This ensures that more than $1 / 2$ of the variance is covered by latent construct [58]. Secondly, all the constructs must have at least 0.70 of reliability and 0.50 of average variance extracted (AVE). In our research, all the factor loadings are more than 0.70 and they are significant at 0.001 level. Moreover, composite reliabilities exceed 0.70 with a minimum of 0.79 (Table II). Table III shows the average variance extracted. All the numbers are over 0.50 with a minimum of 0.68 . So, convergent validity is satisfied.

To test the discriminant validity of the scales, we used square root of average variance extracted and construct item loadings. For square roots, it has been advised that each construct must have higher inter-construct coefficients [59]. Table III shows that all square toots of AVEs are the highest numbers in coefficients (the highest is 0.89 for ethical obligation and the lowest is 0.68 for ego strength). Moreover, for construct item loadings they recommend that loadings of within-constructs must be at least 0.10 higher than the cross loadings of inter-constructs. Our research satisfies this criterion. Thus, the discriminant validity of the scales is approved.

TABLE III. AVERAGE VARIANCE EXTRACTED

\begin{tabular}{|c|c|c|c|c|c|c|c|}
\hline & PI & EJ & EO & PD & LOC & ES & LC \\
\hline PI & 0.81 & & & & & & \\
\hline EJ & 0.49 & 0.76 & & & & & \\
\hline EO & 0.49 & 0.44 & 0.89 & & & & \\
\hline PD & 0.47 & 0.42 & 0.39 & 0.88 & & & \\
\hline LOC & 0.33 & 0.38 & 0.36 & 0.43 & 0.77 & & \\
\hline ES & 0.32 & 0.30 & 0.26 & 0.40 & 0.41 & 0.68 & \\
\hline LC & 0.29 & 0.28 & 0.18 & 0.35 & 0.29 & 0.39 & 0.73 \\
\hline
\end{tabular}

\section{RESULTS}

Having a valid and reliable model for ethical decision making in the context of information technology, we tested our hypotheses. As depicted in Figure 2, results showed that at the significance level of $\mathrm{p}<0.05$, all hypothesized paths are confirmed except for the direct paths from law to ethical obligation $(\mathrm{B}=0.02$ and $\mathrm{t}$-value $=0.13)$ and codes of ethics to ethical intention $(B=0.01$ and $t$-value $=0.11)$. Figure 2 also shows $\mathrm{R}^{2}$ values for dependent variables of ethical judgment (0.16), ethical obligation (0.48), and ethical intention (0.32). Moreover, two paths for indirect effects are as follows:

- Perceived importance on ethical intention through ethical judgment;

- $\quad$ Ethical judgment on ethical intention through ethical obligation.

The indirect effect of law on ethical intention is not significant since the direct path from law to ethical obligation is not significant $(\mathrm{B}=0.02$ and $\mathrm{t}$-value $=0.13)$. Considering direct and indirect effects, the total effects on ethical intention are 0.62 for perceived possibility of disclosure, 0.80 for perceived importance, 0.51 for ethical judgment, 0.24 for ethical obligation, 0.43 for ego strength, and 0.44 for locus of control. In addition, $32 \%$ of the variance of ethical intention is explained by perceived possibility of disclosure, perceived importance, ethical judgment, ego strength and locus of control. Furthermore, $29 \%$ of the variance of ethical judgment is explained by perceived importance and $48 \%$ of the variance of ethical obligation is met by ethical judgment. No unexpected path is revealed.

\section{DISCUSSION}

Perceived importance has a significant direct effect on ethical intention; therefore hypothesis $\mathrm{H} 1 \mathrm{a}$ is confirmed. Perceived importance has been a valid and widely used construct in ethical decision making models. In [64], authors declared that if perceived importance of an ethical issue in an individual is high, the intention to commit an unethical action is low. This is in accordance with the findings of the present study. This is due to the perception of the decision makers that implies the degree of criticalness of the situation [65]. It was also found that perceived importance positively affects ethical judgment (H1b) and ethical judgment affects ethical intention (H2). Thus H1b and H2 are confirmed. 
Concerning the impact of ethical judgment on ethical intention, our finding supports previous endeavors [27, 28, 31]. This happens regardless of the context of decision making; either IT or non-IT. In [66], authors stated that when a person is higher in ethical judgment, he/she tends to commit a higher ethical decision. In [67], authors redefined ethical judgment as the way a person evaluates which actions fit which occasions. Since ethical judgment is commonly met by immediate and routine mental process [26], this reveals the logic behind the impact of ethical judgment on intention. An indirect effect of perceived importance on ethical intention through ethical judgment was observed. The same finding were reported in [64]. This is in accordance with $[14,65]$ that uncovered the role of perceived importance on ethical intention in an IT context. To interpret this relation, we may justify that if someone perceives a high-important issue, their ethical judgment strengthens and this lowers their intention level.

In the third hypothesis, we investigated the impact of ethical judgment on ethical obligation and found that ethical judgment is an indicator of ethical obligation. Although there are no evidences about this hypothesis in IT, a significant impact among U.S. business students has been reported in [65]. The impact of ethical obligation on ethical intention was tested in the fourth hypothesis and we observed a direct impact. Similarly, In [36], authors found a positive relation between ethical obligation and intention among computer college students. Earlier, this relation was put into test between 423 United States' students of computing classes with the same findings [15]. Likewise, in [23] authors presented similar results with IT-based scenarios.

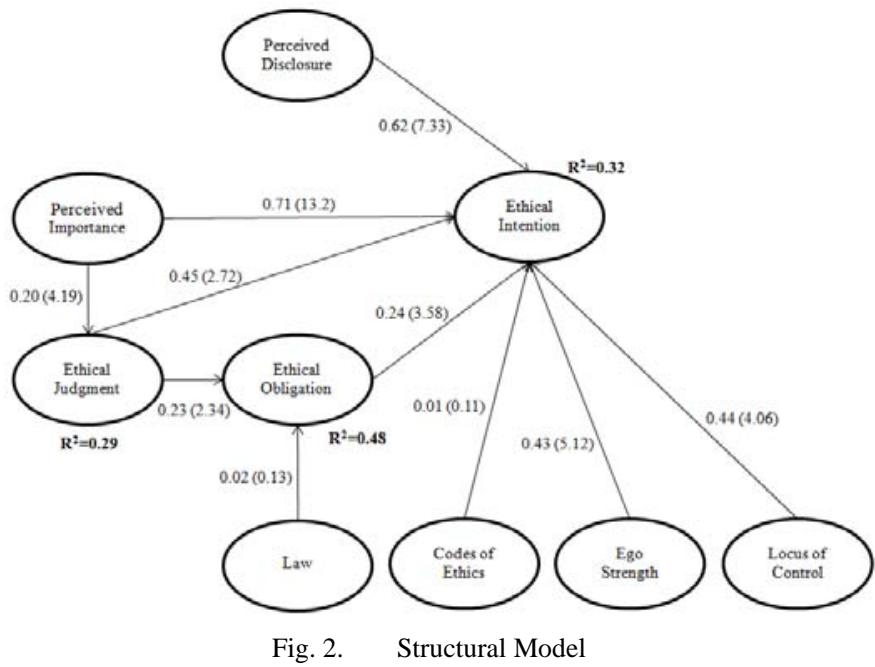

In our research, we did not find any meaningful impact from law on ethical obligation and codes of ethics on ethical intention. So, H5 and H6 are not confirmed. There have been contradictory findings concerning law and codes of ethics. For instance, in [17] authors found that law (legal perception) has a positive impact on ethical obligation only in two of their five scenarios. They concluded that among automobile sales people, law is not an indicator of ethical obligation. On the other hand, in [68], authors showed that codes of ethics are a substantial indicator in predicting ethical intention among Hong King's companies. In [2], it was argued that although individuals may be aware of laws in their society or organizational norms, but they prefer not to adhere to them. He then adds that this might be due to their understandings of law and codes of ethics as a behavior-limiting factor in ethical decision making [69]. Instead, law and codes of ethics must be an integral part of the behavior of every individual.

We may refer to three reasons why the impact of law on ethical obligation is not supported. First, the enactment of cyber-space laws in Iran goes back to 2000s. For instance, Computer Crimes Law (enacted in 2009), Electronic Commerce Law (enacted in 2004), and Supporting Software Developers' Rights Law or namely Copyright Law (enacted in 2000) are only a decade old and contain a number of problems that affect their applicability and efficiency [70]. Moreover, the majority of people in Iran, even IT professionals, are not familiar with laws [71]. Furthermore, designated punishments in the above mentioned laws are not preventive measures. Almost the same reasons may apply to codes of ethics. In [2], it was propsoed that law and codes of ethics may be proper mechanisms to prevent unethical actions through organizations. However, regarding our findings in IT ethics, this domain requires further investigations.

Considering hypotheses 7 and 8, like other researchers, we found that ego strength and locus of control each have direct impact on ethical intention. In [54], the same finding among managers in the United States was reported. It was affirmed that locus of control is an indicator of ethical decision making, but functions differently for people with internal or external locus of control. The one who looks at others and takes his/her decisions based on their actions, has more powerful external locus of control and the one who takes decisions individually, possesses more influential internal locus of control. A crosscountry research between U.S. and Taiwan business managers revealed that locus of control was an indicator of ethical intention, but it was more significant in Taiwan [71]. However, findings in another IT study between university students in Malaysia revealed that locus of control and ego strength do not affect intention [23]. In an IT context, in [14] it was found that ego strength has a direct effect on ethical intention, but they did not report the same for locus of control. This contradiction may be referred to different scenarios and samples. Further investigations may clarify the role of locus of control and ego strength.

In the ninth hypothesis, we noted a direct impact from perceived possibility of disclosure on ethical intention. Thus, H9 is confirmed. As we stated earlier, we developed perceived possibility of disclosure as a new construct in the decision making context. To further investigate the impact of perceived disclosure on ethical decision making, we conducted a simple survey based on six unethical scenarios originally derived from [6]. Each scenario is followed by a single question: "if you were $100 \%$ sure that nobody will understand that you have had committed this action, how likely would you do it?" Respondents were to choose from six answers: impossible (scored 0); very unlikely (scored 1); unlikely (scored 2); maybe (scored 3); likely (scored 4); and very likely (scored 5). They 
were assured that their responses will be confidentially saved solely for research purposes. The results of analyzing 166 returned questionnaires revealed astounding facts (Table IV). Regardless of the scenarios, by average, more than 82 percent of the respondents claimed to "likely" or "very likely" would do the unethical action. It is notable that only 16 persons of the respondents (about 10\%) reported "impossible" or "very unlikely" to the scenarios.

TABLE IV. RESULTS OF ANALYZING SCENARIOS

\begin{tabular}{|c|c|c|c|c|}
\hline Scenario & Ave.* (\%) & STDEV. & $\begin{array}{c}\text { No. of } \\
\text { responses } \\
\text { scored 4 or 5 }\end{array}$ & $\begin{array}{c}\text { \% of } \\
\text { responses } \\
\text { scored 4 or 5 }\end{array}$ \\
\hline No. 1 & $3.99(79.76)$ & 1.34 & 124 & 77.01 \\
\hline No. 2 & $4.01(80.12)$ & 1.29 & 117 & 72.67 \\
\hline No. 3 & $3.99(79.76)$ & 1.23 & 120 & 74.53 \\
\hline No. 4 & $4.13(82.65)$ & 1.16 & 130 & 80.74 \\
\hline No. 5 & $4.34(86.75)$ & 1.03 & 142 & 88.19 \\
\hline No. 6 & $4.23(84.70)$ & 1.18 & 134 & 83.22 \\
\hline Total & $4.12(82.31)$ & 0.50 & - & 82.31 \\
\hline
\end{tabular}

\section{CONCLUSIONS}

In this study we tried to model how an ethical decision is made in an information technology context. Our findings approved previous endeavors that perceived importance of an issue, ethical judgment, ethical obligation, ego strength and locus of control affect one's ethical intention. Further, the possibility of disclosure surfaces as a significant factor. Moreover, it was found that law and codes of ethics do not affect ethical intention. This is in alignment and also contradiction with previous research studies. To mention this research's limitations, we might refer to the possible impact of religion on ethical intention. However, it has been proposed that this factor has a low impact on the IT field [73] and even the core logic behind this argument has been challenged [23]. The same argument can be supported for culture [74]. Finally gender and demographic factors have not been considered, and this should be a field for future studies.

\section{APPENDIX}

All the names (persons and companies) in the following scenarios are imaginary. Any similarity is unintentional.

Scenario 1: Target Marketing in Banks

Alfa Bank, as the biggest public bank of the country, owns a business intelligence system to validate customers and offer marketing plans for each accredited customer individually. Mason, an information technology expert who was involved in the development of the business intelligence system, has authorized access to its data warehouse. He has a friend, James, in one of the branches of the Alfa Bank. Mason extracts a list of customers who are recommended to be offered with ease-loan (a loan that is easily payable to a customer due to his/her credits) and gives it to James. He calls each customer and offers an ease-loan with a commission of 2 percents. Mason and James share the commission. After that, Mason permanently deletes the records of the customers from the data warehouse.

Scenario 2: Health Information System

The Ministry of Health Affairs employs a Health Information System (HIS) with a module named "fraud detection". This module helps find forged medical documents and expenses. All the public and private hospitals and institutes have controlled and authorized access to the information system. Dr. Brooks, a general practitioner employed in the Ministry of Health Affairs, has been engaged in the process of HIS development to clarify business requirements. Accidentally, he has an admin access to HIS since the information system is published country-wide. Dr. Brooks, as a user of the system, frequently uses admin features to ease and facilitate working processes and to avoid bureaucracy.

Scenario 3: Insurance Database

Milton, a graduate student in software engineering, works for Marion Insurance Company. He has an authorized access to the database with more than 100 million records. As a part of his job, Milton extracts rules (rule extraction) by data mining techniques and reports to his supervisor. For instance, he finds that those customers who are younger than 24, are single and have a record of more than one accident, are classified as high risk customers. Milton decides to document the data mining process and hand-in a collection of the rules to his data mining course in university.

Scenario 4: Widget Development

Felix is a software developer and works in a company that sells and supports software packages. The company has numerous projects. Felix is a member of a team that works on developing a Financial Management System (FMS). He has developed a reporting widget which delivers customized and drill-down features. Since Felix has developed the widget by himself, he also uses its source code in a software package that he is developing for himself at weekends at home.

\section{Scenario 5: Stockbroker}

Dalton Stockbroker Corporation has a Decision Support System (DSS) which analyzes stock exchange transactions and generates short-term buy-orsell quotes using a neural network engine. This company offers a monthly membership plan for 25 USD and presents at least 15 quotes. Sheridan, an IT specialist in the company, has an authorized access to DSS and she is responsible for database maintenance. She extracts quotes daily and sends a few of them to her husband to buy or sell stocks and earn profits.

Scenario 6: Witnessing Data Breach

Sarah has recently graduated from a famous national university and holds a Bachelor of Science in computer engineering. She really needs money and has found a job in an IT company which is responsible for developing a business intelligence system for the biggest private bank in the country. On the first day of the work, she signs a document stating company's codes of ethics and declares to obey it. After two weeks, Sarah accidentally finds that a few of her coworkers sell customers' data to a marketing company and finds it in contradiction to the codes of ethics. Since Sarah really needs this job, she decides not to report this.

\section{REFERENCES}

[1] D. C. Menzel, Ethics Management for Public Administrators: Building Organizations of Integrity, 2nd ed. Abingdon: Routledge, 2012

[2] S. L. Christensen, "The Role of Law in Models of Ethical Behavior", Journal of Business Ethics, Vol. 77, No. 1, pp. 451-461, 2008

[3] L. K. Treviño, G. R. Weaver, S. J. Reynolds, "Behavioral Ethics in Organizations: A Review", Journal of Management, Vol. 32, No. 6, pp. 951-990, 2006

[4] V. J. Calluzzo, C. J Cante, "Ethics in Information Technology and Software Use", Journal of Business Ethics, Vol. 51, pp. 301-312, 2004

[5] L. T. Hosmer, The Ethics of Management, 7th ed. NY: McGraw-Hill Education, 2010

[6] E. Turban, R. Sharda, D. Delen, D. King, Business Intelligence: a Managerial Approach.: Prentice Hall, 2010R. A. Schultz, Contemporary issues in ethics and information technology. United States: IRM Press, Yurchak Printing Inc., 2006

[7] T. W. Loe, L. Ferrell, P. Mansfield, "A Review of Empirical Studies Assessing Ethical Decision Making in Business", Vol. 25, No. 3, pp. 85204, 2000

[8] K. D. Loch, S. Conger, "Evaluating ethical decision making and computer use", Communications of the ACM, Vol. 39, No. 7, pp. 74-83, 1996

[9] C. Beghtol, "Ethical decision-making for knowledge representation and organization systems for global use", Journal of the American Society for Information Science and Technology, Vol. 56, No. 9, pp. 903-912, 2005 
[10] J. M. McMahon, R. Cohen, "Lost in cyberspace: ethical decision making in the online environment", Ethics and Information Technology, Vol. 11, No. 1, pp. 1-17, 2009

[11] E. Erturk, "The Impact of Intellectual Property Policies on Ethical Attitudes toward Internet Piracy", Journal of Knowledge Management, Vol. 12, No. 1, pp. 101-109, 2013

[12] D. Banerjee, T. P. Cronan, T. W. Jones, "Modeling IT Ethics: A Study in Situational Ethics", MIS Quarterly, Vol. 22, No. 1, pp. 31-60, 1998

[13] L. N. K Leonard, T. P. Cronan, "Illegal, Inappropriate, And Unethical Behavior In An Information Technology Context: A Study To Explain Influences", Journal of the Association for Information Systems, Vol. 1, No. 1, pp. 1-31, 2001

[14] L. N. K. Leonard, T. P. Cronan, J. Kreie, "What influences IT ethical behavior intentions-planned behavior, reasoned action, perceived importance, or individual characteristics?", Information \& Management, Vol. 42, pp. 143-158, 2004

[15] C. A. Dorantes, B. Hewitt, T. Goles, "Ethical Decision-Making in an IT Context: The Roles of Personal Moral Philosophies and Moral Intensity", in The 39th Hawaii International Conference on System Sciences, Hawaii, 2006, pp. 1-10

[16] E. D. Honeycutt Jr, M. Glassman, M. T. Zugelder, K. Karande, "Determinants of Ethical Behavior: A Study of Autosalespeople", Journal of Business Ethics, Vol. 32, No. 1, pp. 69-79, 2001

[17] T. M. Jones, "Ethical Decision Making by Individuals in Organizations: An Issue-Contingent Model", The Academy of Management Review, Vol. 16, No. 2, pp. 366-395, 1991

[18] O. C. Ferrell, L. G. Gresham, "A Contingency Framework for Understanding Ethical Decision Making in Marketing", Journal of Marketing, Vol. 49, No. 3, pp. 87-96, 1985

[19] D. P. Robin, R. E. Reidenbach, P. J. Forrest, "The perceived importance of an ethical issue as an influence on the ethical decision-making of ad managers", Journal of Business Research, Vol. 35, No. 1, pp. 17-28, 1996

[20] J. G. P. Paolillo, S. J. Vitell, "An empirical investigation of the influence of selected personal, organizational and moral intensity factors on ethical decision making", Journal of Business Ethics, Vol. 35, No. 1, p. 65, 2002

[21] S. A. Morris, R. A. McDonald, "The Role of Moral Intensity in Moral Judgments: An Empirical Investigation", Journal of Business Ethics, Vol. 14, No. 9, pp. 715-726, 1995

[22] H. Jafarkarimi, R. Saadatdoost, A. T. H. Sim, J. M. Hee, "Behavioral intention in social networking sites ethical dilemmas: An extended model based on Theory of Planned Behavior", Computers in Human Behavior, Vol. 62, No. 1, pp. 545-561, 2016

[23] R. Bregman, D. X. Peng, W. Chin, "The effect of controversial global sourcing practices on the ethical judgments and intentions of U.S. consumers", Journal of Operations Management, Vol. 36, No. 1, pp. 229-243, 2015

[24] J. R. Rest, Moral Development: Advances in Research and Theory. New York: Praeger, 1987

[25] J. Haidt, "The emotional dog and its rational tail: a social intuitionist approach to moral judgment", Psychological Review, Vol. 108, No. 4, pp. 814-834, 2001

[26] J. M. Logsdon, J. K. Thompson, R. A. Reid, "Software piracy: Is it related to level of moral judgment?", Journal of Business Ethics, Vol. 13, No. 11, p. 849, 1994

[27] T. Bass, K. Barnett, G. Brown, "Religiosity, Ethical Ideology, and Intentions to Report a Peer's Wrongdoing", Journal of Business Ethics, Vol. 15, No. 11, pp. 1161-1174, 1996

[28] T. Barnetta, S. Valentine, "Issue contingencies and marketers' recognition of ethical issues, ethical judgments and behavioral intentions", Journal of Business Research, Vol. 57, pp. 338 - 346, 2004

[29] A. Singhapakdi, S. J. Vitell, G. R. Franke, "Antecedents, Consequences, Mediating Effects of Perceived Moral Intensity and Personal Moral Philosophies", Journal of the Academy of Marketing Science, Vol. 27, No. 1, pp. 19-36, 1999
[30] R. Haines, L. N. K. Leonard, "Situational influences on ethical decisionmaking in an IT context", Information \& Management, Vol. 44, No. 3, pp. 313-320, 2007

[31] W. E. Shafer, R. E. Morris, A. A. Ketchand, "Effects of personal values on auditors' ethical decisions", Accounting, Auditing \& Accountability Journal, Vol. 14, No. 3, pp. 254 - 277, 2001

[32] T. Barnett, "Dimensions of Moral Intensity and Ethical Decision Making: An Empirical Study", Journal of Applied Social Psychology, Vol. 31, No. 5, pp. 1038-1057, 2001

[33] R. J. Budd, C. P. Spencer, "Exploring the role of personal normative beliefs in the theory of reasoned action: The problem of discriminating between alternative path models", European Journal of Social Psychology, Vol. 15, No. 3, pp. 299-313, 1985

[34] Shalom H Schwartz and Richard C Tessler, "A test of a model for reducing measured attitude-behavior discrepancies", Journal of Personality and Social Psychology, Vol. 24, No. 2, pp. 225-236, 1972

[35] R. Haines, L. N. K. Leonard, "Individual characteristics and ethical decision - making in an IT context", Industrial Management \& Data Systems, Vol. 107, No. 1, pp. 5-20, 2007

[36] F. A. Fagothey, Right and Reason, 2nd ed. Rockford, IL: Tan Books and Publishers, 1959

[37] T. L. Beauchamp and N. E. Bowie, Ethical theory and business. N.J Englewood Cliffs: Prentice Hall, 1993

[38] T. Dunfee, "On the Synergistic, Interdependent Relationship of Business Ethics and Law", American Business Law Journal, Vol. 34, No. 2, pp. 317-328, 1996

[39] S. Harrington, "The Effects of Codes of Ethics and Personal Denials of Responsibility on Computer Abuse Judgments and Intentions", MIS Quarterly, Vol. 20, No. 3, pp. 257-278, 1996

[40] S. D. Hunt, S. Vitell, "The General Theory of Marketing Ethics: A Retrospective and Revision", in Ethics in Marketing. Homewood: Richard D Irwin, 1993, pp. 775-784

[41] M. S. Hagger, C. Wood, C. Stiff, N. L. D. Chatzisarantis, "Ego depletion and the strength model of self-control: a meta-analysis", Psychological Bulletin, Vol. 136, No. 4, pp. 495-525, 2010

[42] B. Moore, B. Fine, Psychoanalytic Terms and Concepts. New Haven, CT: Yale University Press, 1990

[43] P. D. Kramer, "American Psychiatric Press Review of Psychiatry", American Journal of Psychiatry, Vol. 153, No. 10, pp. 1358-1358, 1996

[44] N. Ozcaglar-Toulouse, Edward Shiu, and Deirdre Shaw, "In search of fair trade: ethical consumer decision making in France", International Journal of Consumer Studies, Vol. 30, No. 5, pp. 502-514, 2006

[45] N. Michaelidou, L. M. Hassan, "The role of health consciousness, food safety concern and ethical identity on attitudes and intentions towards organic food", International Journal of Consumer Studies, Vol. 32, No. 2, pp. 163-170, 2008

[46] D. Shaw, E. Shiu, "An assessment of ethical obligation and self-identity in ethical consumer decision-making: a structural equation modelling approach", International Journal of Consumer Studies, Vol. 26, No. 4, pp. 286-293, 2002

[47] L. Klebe Trevino, "Ethical decision making in organizations: a personsituation interactionist", Vol. 11, No. 3, pp. 601-617, 1986

[48] J. B. Rotter, "Generalized expectancies for internal versus external control of reinforcement", Psychological Monographs: General and Applied, Vol. 80, No. 1, pp. 1-28, 1966

[49] J. Cherry, J. Fraedrich, "An Empirical Investigation of Locus of Control and the Structure of Moral Reasoning: Examining the Ethical DecisionMaking Processes of Sales Managers", The Journal of Personal Selling and Sales Management, Vol. 20, No. 3, pp. 173-188, 2000

[50] M. C. Reiss, K. Mitra, "The Effects of Individual Difference Factors on the Acceptability of Ethical and Unethical Workplace Behaviors", Journal of Business Ethics, Vol. 17, No. 14, pp. 1581-1593, 1998

[51] W. H. Hegarty, H. P. Sims, "Some determinants of unethical decision behavior: An experiment", Journal of Applied Psychology, Vol. 63, No. 4, pp. 451-457, 1978

[52] W. H. Hegarty, H. P. Sims, "Organizational philosophy, policies, and objectives related to unethical decision behavior: A laboratory 
experiment", Journal of Applied Psychology, Vol. 64, No. 3, pp. 331338, 1979

[53] A. Forte, "Locus of Control and the Moral Reasoning of Managers", Journal of Business Ethics, Vol. 58, No. 1, pp. 65-77, 2005

[54] T. A. Heberlein, "Social norms and environmental quality", in The annual meeting of the American Association for the Advancement of Science, New York, 1975

[55] J. S. Adams, A. Tashchian, T. H. Shore, "Codes of Ethics as Signals for Ethical Behavior", Journal of Business Ethics, Vol. 29, No. 3, pp. 199211, 2001

[56] N. Gorla, T. M. Somersb, B. Wong, "Organizational impact of system quality, information quality, and service quality", Journal of Strategic Information Systems, Vol. 19, No. 3, pp. 207-228, 2010

[57] W. L. Kuechler, A. McLeod, M. G. Simkin, "Why Don't More Students Major in IS?", Decision Sciences Journal of Innovative Education, Vol. 7, No. 2, pp. 463-488, 2009

[58] D. Gefen, D. Straub, "A Practical Guide To Factorial Validity Using PLSGraph: Tutorial And Annotated Example", Communications of the Association for Information Systems, Vol. 16, No. 5, pp. 91-109, 2005

[59] T. Verhagen, W. M. van Dolen, "Online purchase intentions: A multichannel store image perspective", Information \& Management, Vol. 46, No. 2, pp. 77-82, 2009

[60] D, Straub, M. Boudreau, D. Gefen, "Validation guidelines for IS positivist research", Communications of the Association for Information Systems, Vol. 13, pp. 380-427, 2004

[61] R. F. DeVellis, Scale development: Theory and applications. Los Angeles: Sage, 2012

[62] C. Fornell, D. F. Larcker, "Evaluating Structural Equation Models with Unobservable Variables and Measurement Error", Journal of Marketing Research, Vol. 18, No. 1, pp. 39-50, 1981

[63] D. P. Robin, R. E. Reidenbach, P. J. Forrest, "The perceived importance of an ethical issue as an influence on the ethical decision making of ad managers", Journal of Business Research, Vol. 35, pp. 17-28, 1996
[64] R. Haines, M. D. Street, D. Haines, "The Influence of Perceived Importance of an Ethical Issue on Moral Judgment, Moral Obligation, and Moral Intent", Journal of Business Ethics, Vol. 81, No. 2, pp. 387399, 2008

[65] G. Fleischman, S. Valentine, "Professionals' Tax Liability Assessments and Ethical Evaluations in an Equitable Relief Innocent Spouse Case", Journal of Business Ethics, Vol. 42, No. 1, pp. 27-44, 2003

[66] E. Dane, S. Sonenshein, "On the role of experience in ethical decision making at work: An ethical expertise perspective", Organizational Psychology Review, Vol. 5, No. 1, pp. 1-23, 2014

[67] R. S. Snell, N. C. Jr Herndon, "Hong Kong's Code of Ethics Initiative: Some Differences between Theory and Practice", Journal of Business Ethics, Vol. 51, No. 1, pp. 75-89, 2004

[68] J. Nesteruk, "Reimagining the Law", Business Ethics Quarterly, Vol. 9, No. 4, pp. 603-617, 1999

[69] P. Savaraee, "A Critique on Electronic Commerce Law", Law Research Magazine, Vol. 22, No. 4, pp. 369-403, 2013

[70] A. Shahmohammadi, A. Taati, "A study of social webblogers' acquaintance with the internet laws and crimes", Culture of Communication, Vol. 1, No. 3, pp. 105-120, 2011

[71] J. Cherry, "The impact of normative influence and locus of control on ethical judgments and intentions: A cross-cultural comparison", Journal of Business Ethics, Vol. 68, No. 2, pp. 113-132, 2006

[72] J. Migga Kizza, Ethical and Social Issues in the Information Age. London: Springer-Verlag, 2013

[73] N. L. Martin, B. S. Woodward, "Computer Ethics of American and European Information Technology Students: A Cross-Cultural Comparison", Issues in Information Systems, Vol. 12, No. 1, pp. 78-87, 2011 